\title{
Profitability of Coal Mining Sectors in IDX: Effects of CSR Disclosure, Leverage and Size
}

\author{
Ristati $^{1}$, Marzuki ${ }^{1}$, Rasyimah ${ }^{1}$, Desi Safitri ${ }^{1}$ and Ghazali Syamni ${ }^{2}$ \\ \{ristati_bere@yahoo.com,marzuki@fe-unimal.org, rasyimah@hotmail.com,desisafitri@yahoo.com, \\ syamni_ghazali@yahoo.com\} \\ ${ }^{1}$ Department of Management, Universitas Malikussaleh, Lhokseumawe, Aceh -Indonesia \\ ${ }^{2}$ Universitas Malikussaleh and Ph.D Student in Doctorate program in Management, University of Syiah \\ Kuala Banda Aceh-Indonesia
}

\begin{abstract}
The objectives this study aims to examine the influence of Corporate Social Responsibility (CSR) disclosure, debt level and size of mining company companies in Indonesia Stock Exchange. The data analysed in this research comes from mining company registered in IDX during 2012-2015. This research applies model of regression analysis of panel data with Chow and Hausman test as the best model selection. The results of the study find that the profitability by return on asset in the mining company is largely determined by debt level. This finding indicates that the debt held by the mining company causes decrease on return on assets.
\end{abstract}

Keywords: profitability, mining, csr, idx

\section{Introduction}

Mining undoubtedly plays an important role in industry world wide. Particularly in Indonesia, where the mineral resources are abundant and dispersed widely in the whole country, this sector has become one of major industries with great impact in the economy. The mining industry definitely requires sources of large investment. Mining industries has been using source of fossil energy which has been decreasingly used for development in several decades. This is in line with (Hung et al., 2018) state that mining is an industrial sector has become a backbone of sustainable development and industrialization in this modern era. Thus, mining targeted companies are required to possess considerable funds in attempting to involve in this industry. Since it is insufficient to rely solely on the company's internal capital, companies are obliged to join the stock exchange to seek investment. The entry of companies into the stock exchange provides greater access to gain investor capital so that it can perform better exploration which ultimately leads to profitability increase for the company.

A company engaged in the energy or mineral resources sector is expected to comply with a standard obligation concerning to the environment. The obligation is stipulated in a Law of the Republic of Indonesia Number 40 of 2007. In the law it is said that the company related to the energy or resources is mandated to perform social and environmental responsibility and report its implementation in the financial statements. The company's accountability report is prepared by taking into account all the interests of shareholders or all parties concerned with the use of financial statements. The accountability report is known as Corporate Social Responsibility (CSR). This CSR is not only voluntary but also concerns the decisions that legitimately affect stakeholders and the environment. The CSR-related decisions yield greater profitability(Giannarakis et al., 2016; Price and Sun, 2017; Kim, Kim and Qian, 2018; Sun et al., 2018). Several research mentioned that profitability is strongly influenced by CSR either 
negatively or positively. The study used Standard \& Poor's data in America by (Giannarakis et al., 2016) pointed out how CSR was linked with companies' profitability. (Kim, Kim and Qian, 2018) using 113 software industry claimed CSR positively influences financial performance on highly competetive companies and negatively on less competitive companies. In addition, (Price and Sun, 2017) found companies performing minimum CSR were exceeding compared with CSR-negligent companies. In China, (Sun et al., 2018) stated that there was a negative relationship with investor sentiment which was greater in government companies. Nevertheless, research in some countries also revealed different results of how CSR disclosure influenced company profitability. (Ngoc, 2018) focusing on banking companies in Vietnam, revealed disclosure of CSR negatively affect the profitability of banking companies. (Bodhanwala and Bodhanwala, 2018; Maqbool and Zameer, 2018) who focused data on 28 commercial banks and 58 firms in the India Stock Exchange claimed significant effect of CSR on financial performance.

The differences of the research's results mentioned previously are explicable due to characteristics and strategies of the CSR's implementation. (Alhouti, Johnson and Holloway, 2016) pointed out that profitability reducing circumstances were the result of superficial impact of CSR's application on consumers or the environment. Meanwhile (Bhardwaj et al., 2018) explained that CSR affected profitability positively if the implementation was considered successful or appreciated by consumers and the environment. However, (Al-Dah, Dah and Jizi, 2018) mentioned that contentment in the implementation of CSR was dependent on the macroeconomic environment.

In addition to CSR, mining companies requiring large amounts of funds were likely to be exposed to the level of debt ratio and size of the company. The level of debt ratio also affected the level of profitability in mining companies. The claim was based on the research by(González, 2013; Vithessonthi and Tongurai, 2015; Bae, Kim and Oh, 2017; Abel, 2018; Ibhagui and Olokoyo, 2018; Nisha and Ghosh, 2018; Odusanya, Yinusa and Ilo, 2018). On the other hand the level of debt also affected the profitability of the firm but was highly dependent on optimal debt levels (Abel, 2018). (González, 2013)focusing on 39 countries, explained that leverage levels would reduce the company's performance. (Bae, Kim and Oh, 2017) explained the relationship of debt-to-financial ratio to financial performance. Research in developing countries also revealed various results. (Ibhagui and Olokoyo, 2018) using data from 101 companies in Nigeria, leverage had negative influence on the profitability of Tobin's' Q. (Nisha and Ghosh, 2018)showed that the profitability of leverage and non leverage companies at the Dhaka Stock Exchange were influenced indistinguishably. In the Nigerian Stock Exchange by (Odusanya, Yinusa and Ilo, 2018)the level of short-term negative debt affected profitability at 114 companies. In Pakistan, (Bhatti, 2011) revealed that the level of debt would encourage profitability. Meanwhile, in a study at the Amman Stock Exchange, Jordan, by (Warrad, 2017) also showed the effect of ratio of leverage debt on the profitability of industrial companies. However, research in Thailand by (Vithessonthi and Tongurai, 2015) leverage caused different influences on small and large firms where the small firms were negatively influenced and large companies vice versa.

Regarding with the companies' size, (Olaniyi et al., 2017) discovered that it affected profitability of the companies that they investigated. (Olawale, Ilo and Lawal, 2017) claimed that the companies' size affected return on equity performance in non-financial companies. (Murrar, 2017) research in Palestine, found companies' size in affected profitability differently, but profitability was better affected in larger companies. However, (Niresh and Velnampy, 2014) at the Colombo Stock Exchange, Sri Lanka, pointed out the relation between 
the size of the companies with the profitability were somewhat non existence in manufacturing companies.

Meanwhile, some research in Indonesia itself also experienced inconsistent results relating to the three variables used. (Rofiqkoh and Priyadi, 2017) explained that there was no effect of profitability from CSR's disclosure. (Supianto and Warneri, 2012) proved that profitability was negatively affected by debt ratio. (Thomas et al., 2016) mentioned that leverage insignificantly affected profitability. (Lestari, Puspitaningtyas and Prakoso, 2018) claimed welfare costs as CSR would affect return on assets in goods and consumption companies. (Tiarasandy, Yuliandari and Triyanto, 2018) stated there was no relation between CSR's disclosure to company performance. (Umiyati and Baiquni, 2018) pointed out how companies' size affected ROA profitability, ROE in Indonesian' Proper companies.

\section{Methodology}

Data used in this research was data documentation of financial report of mining company during period of 2013-2015. The sampled companies in this research were 9 companies from 23 mining companies listed in IDX. All data was accessed on the page of the financial services authority in the mining sector and that meets the criteria of 9 stocks. The criteria used such as the published financial statements during the sample period and financial statements disclosed also in the period under study. Because there were only 9 companies eligible, then all data from 9 companies was interpolated in quarterly data so that the number of observations were 36 observations. After the interpolation of data in 36 subsequent observations tabulation was performed based on the proxies used as represented variables in this study. The variables used in this study was profitability which is procured with Return on Assets (ROA), CSR disclosure proxy with CSRDI, leverage ratio was proxied with debt equity ratio (DER) as well as company size proxied with total asset. Based on the data used was panel data then the regression model used in this research was panel regression. Then, the last model developed in this study was

$\mathrm{ROA}_{i t}=\alpha_{\mathrm{it}}+\mathrm{CSRDI}_{\mathrm{it}}+\mathrm{DER}_{\mathrm{it}}+\mathrm{TOA}_{\mathrm{it}}+\varepsilon_{\mathrm{it}}$

Model selection was performed in order to acquire a decent research model in panel regression. Model selection was done by testing Chow and Hausman. Chow test was conducted to choose the model of common effect panel model regression with fixed effect model. If the chi square probability was significant then the best model was the fixed effect model, and the Hausman test was required. Hausman test was done to choose the model of fixed effect or random effect. If the chi square probability was not significant then the best model is the random effect model, while if the chi square probability was significant then the best model was the fixed effect model. Conversely, if the probability is not significant then the common effect model would serve as the best model and unnecessary to be followed by Hausman test (Baltagi, Bresson and Pirotte, 2003) and (Zariyawati, Annuar and Pui-San, 2016).

\section{Result And Discussions}

Before discussing the results of regression testing, the selected model selection would be discussed along with the list of Table 1 below. Based on Table 1 above it can be explained that the correct model in this research was Random Effect Model (REM). Selection of REM model was due to Chow test result which was clear from cross section value Chi Square significant 
with value 8 and significant 0.0099 . This result requires a further test of the Hausman test. After the Hausman test resulted a value of 3 and insignificant. So the best model is Random Effect Model (Zariyawati, Annuar and Pui-San, 2016) and (Baltagi, Bresson and Pirotte, 2003).

Table 1. Result discussion determinant of return on asset

\begin{tabular}{lccr}
\hline $\begin{array}{c}\text { Variables } \\
\text { coefficient }\end{array}$ & $\begin{array}{c}\text { Common } \\
\text { Effect } \\
\text { Model } \\
\text { (CEM) }\end{array}$ & $\begin{array}{c}\text { Fixed } \\
\text { Effect } \\
\text { Model } \\
\text { (FEM) }\end{array}$ & $\begin{array}{c}\text { Random } \\
\text { Effect Model } \\
\text { (REM) }\end{array}$ \\
\hline $\mathrm{C}$ & 0.2096 & $0.5663 * *$ & 0.3212 \\
\hline CSRDI & -0.0216 & 0.0196 & -0.0092 \\
\hline DER & -0.0132 & -0.0204 & $-0.0162 *$ \\
\hline Total asset & 0.0007 & -0.0237 & -0.0068 \\
\hline R-Square & 0.1590 & 0.6007 & 0.2038 \\
\hline F-Statistic & 1.450 & $2.0519 *$ & 1.9635 \\
\hline Chow test & & & $8 * *$ \\
\hline $\begin{array}{l}\text { Hausman } \\
\text { test }\end{array}$ & & & 3 \\
\hline $\begin{array}{l}\text { Note: *** significant level 1\%, ** significant level 5\%, * } \\
\text { significant level 10 \% }\end{array}$ &
\end{tabular}

Furthermore, it was submitted this research model based on REM was ROA $=0.3212-$ 0.0092 CSRDI- 0.016 DER- 00068 Total assets. Based on the above equation model, it can be explained with respect to the independent variables used in this study. First, the constant value is 0.3212 which means that if the value of DER, CSRDI and total asset of mining company remain steady, the profitability also increases. Second, CSRDI variable coefficient is negative -0.0092 which means if mining company contribute CSRDI equal to 1 percent, it will decrease profitability of company equal to 0.92 percent. Third, the negative DER coefficient of -0.0162 could be interpreted that if DER in mining companies increases 1 percent it will reduce the profitability of mining companies 1.62 percent. Finally, the same also applies for the coefficient of total assets of mining companies valued -0.0068 . This can be interpreted if the size of the company increases one percent then the profitability of mining companies will decrease by 0.68 percent. In Table 1 above it can also be explained that the ability of mining companies in which all independent variables used in this study namely DER, CSRDI and total assets are unable to explain about profitability dependent variable that is ROA. This is reflected in the $\mathrm{R}^{2}$ value of 20.38 percent. The 20.38 number represents many other factors that affect the profitability of mining companies in Indonesia. In other words, profitability of mining companies in Indonesia are affected by around 80 percent of other variable factors.

\section{Conclussion}

Based on the results of research described above, it clearly shows that only the DER variable that affects the profitability of mining companies in this case return on assets. The finding is consistent as has been suggested by (González, 2013). (Bae, Kim and Oh, 2017) stated that the level of debt in a company would cause a decline in company performance, in particular financial performance. The same is also revealed by (Ibhagui and Olokoyo, 2018)and (Nisha and Ghosh, 2018) that debt has a negative impact on the company. The results of this study also indicate that mining companies profitability, in this case return on 
assets, is not only influenced by DER but there are many other variables that affect the company's performance, such as working capital, coal prices and of course macroeconomic variables of a country. The implications of this research are the recommendations for the owners of firms and investors to avoid over anxiety on the condition of these mining companies. Despite the effect of DER on company profitability, the mining companies still have great prospect.

\section{References}

[1] Abel, A. B. (2018) 'Optimal Debt and Profitability in the Trade-Off Theory', Journal of Finance, 73(1), pp. 95-143. doi: 10.1111/jofi.12590.

[2] Al-Dah, B., Dah, M. and Jizi, M. (2018) 'Is CSR reporting always favorable?', Management Decision, 56(7), pp. 1506-1525. doi: 10.1108/MD-05-2017-0540.

[3] Alhouti, S., Johnson, C. M. and Holloway, B. B. (2016) 'Corporate social responsibility authenticity: Investigating its antecedents and outcomes', Journal of Business Research. Elsevier Inc., 69(3), pp. 1242-1249. doi: 10.1016/j.jbusres.2015.09.007.

[4] Bae, J., Kim, S. J. and Oh, H. (2017) 'Taming polysemous signals: The role of marketing intensity on the relationship between financial leverage and firm performance', Review of Financial Economics. Elsevier Inc., 33, pp. 29-40. doi: 10.1016/j.rfe.2016.12.002.

[5] Baltagi, B. H., Bresson, G. and Pirotte, A. (2003) 'Fixed effects, random effects or Hausman-Taylor?', Economics Letters, 79, pp. 361-369. doi: 10.1016/S01651765(03)00007-7.

[6] Bhardwaj, P., Chatterjee, P., Demir, K. D. and Turut, O. (2018) 'When and how is corporate social responsibility profitable?', Journal of Business Research, 84(November 2016), pp. 206-219. doi: 10.1016/j.jbusres.2017.11.026.

[7] Bhatti, A. R. (2011) Effect of Profitability \& Financial Leverage on Capital Structure: A Case of Pakistan's Automobile Industry, Ssrn. B.com (2011-15) BCOF11M045 Department. doi: 10.2139/ssrn.1911395.

[8] Bodhanwala, S. and Bodhanwala, R. (2018) 'Does corporate sustainability impact firm profitability? Evidence from India', Management Decision, 56(8), pp. 1-15. doi: 10.1108/MD-04-2017-0381.

[9] Giannarakis, G., Konteos, G., Zafeiriou, E. and Partalidou, X. (2016) 'The impact of corporate social responsibility on financial performance', Investment Management and Financial Innovations, 13(3), pp. 171-182. doi: 10.5539/ijbm.v13n3p220.

[10] González, V. M. (2013) 'Leverage and corporate performance: International evidence', International Review of Economics and Finance. Elsevier Inc., 25, pp. 169-184. doi: 10.1016/j.iref.2012.07.005.

[11] Hung, D. N., Thi, H., Ha, V. and Binh, D. T. (2018) 'Impact of Accounting Information on Financial Statements to the Stock Price of the Energy Enterprises Listed on Vietnam 's Stock Market', 8(2), pp. 1-6. doi: ISSN: 2146-4553.

[12] Ibhagui, O. W. and Olokoyo, F. O. (2018) 'Leverage and firm performance: New evidence on the role of firm size', North American Journal of Economics and Finance. Elsevier, 45(February), pp. 57-82. doi: 10.1016/j.najef.2018.02.002.

[13] Kim, K. H., Kim, M. C. and Qian, C. (2018) 'Effects of Corporate Social Responsibility on Corporate Financial Performance: A Competitive-Action Perspective', Journal of Management, 44(3), pp. 1097-1118. doi: 
10.1177/0149206315602530.

[14] Lestari, O. D., Puspitaningtyas, Z. and Prakoso, A. (2018) 'Penerapan Corporate Social Responsibility terhadap Profitabilitas Perusahaan Barang Konsumsi yang Terdaftar di Bursa Efek Indonesia 2012-2016', Ekspektra : Jurnal Bisnis dan Manajemen, 2(1), pp. 89-101.

[15] Maqbool, S. and Zameer, M. N. (2018) 'Corporate social responsibility and financial performance: An empirical analysis of Indian banks', Future Business Journal. Elsevier B.V., 4, pp. 84-93. doi: 10.1016/j.fbj.2017.12.002.

[16] Murrar, A. (2017) 'The Relationship between Size and Performance of Palestinian Water Service Providers', Journal of Water Resource and Protection, 09(05), pp. 536552. doi: 10.4236/jwarp.2017.95035.

[17] Ngoc, N. B. (2018) 'The Effect of Corporate Social Responsibility Disclosure on Financial Performance: Evidence from Credit Institutions in Vietnam', Asian Social Science, 14(4), p. 109. doi: 10.5539/ass.v14n4p109.

[18] Niresh, J. A. and Velnampy, T. (2014) 'Firm Size and Profitability: A Study of Listed Manufacturing Firms ed Manufacturing Firms in Sri Lanka', International Journal of Business and Management, 9(4), pp. 57-64. doi: 10.5539/ijbm.v9n4p57.

[19] Nisha, N. and Ghosh, B. (2018) 'Causal relationship between leverage and performance: exploring Dhaka Stock Exchange', International Journal of Business and Globalisation, 20(1), p. 31. doi: 10.1504/IJBG.2018.10009520.

[20] Odusanya, A. I., Yinusa, O. G. and Ilo, B. M. (2018) 'Determinants of firm profitability in Nigeria: Evidence from dynamic panel models', SPOUDAI, Journal of Economics and Business, 68(1), pp. 43-58. Available at: https://www.researchgate.net/publication/325049840_Determinants_of_Firm_Profitabi lity_in_Nigeria_Evidence_from_Dynamic_Panel_Models.

[21] Olaniyi, C. O., Simon-Oke, O. O., Obembe, O. B. and Bolarinwa, S. T. (2017) 'Reexamining Firm Size-profitability Nexus: Empirical Evidence from Non-financial Listed Firms in Nigeria', Global Business Review, 18(3), pp. 543-558. doi: $10.1177 / 0972150917692064$.

[22] Olawale, L. S., Ilo, B. M. and Lawal, F. K. (2017) 'The Effect of Firm Size on Firms Profitability in Nigeria', THE IEB INTERNATIONAL JOURNAL OF FINANCE, 15(4), pp. 2-21. doi: 10.5605/IEB.15.4.

[23] Price, J. M. and Sun, W. (2017) 'Doing good and doing bad: The impact of corporate social responsibility and irresponsibility on firm performance', Journal of Business Research. Elsevier, 80(July 2015), pp. 82-97. doi: 10.1016/j.jbusres.2017.07.007.

[24] Rofiqkoh, E. and Priyadi, M. P. (2017) 'Pengaruh profitabilitas, leverage dan ukuran perusahaan terhadap pengungkapan tanggung jawab sosial perusahaan', Jurnal Ilmu dan Riset Akuntansi, 10(5), pp. 1-18.

[25] Sun, W., Zhao, C., Wang, Y. and Cho, C. H. (2018) 'Corporate social responsibility disclosure and catering to investor sentiment in China', Management Decision, 56(9), pp. 1917-1935. doi: 10.1108/MD-08-2017-0806.

[26] Supianto, D. and Warneri, W. (2012) 'Pengaruh Rasio Utang Terhadap Profitabilitas pada Perusahaan Makanan dan Minuman Terdaftar di Bursa Efek Indonesia', Jurnal Pendidikan dan Pembelajaran, 2(1), pp. 1-15.

[27] Thomas, A., Lie, D., Siregar, L. and Inrawan, A. (2016) 'Pengaruh Likuiditas Dan Leverage Terhadap Profitabilitas Pada Pt Hanjaya Mandala Sampoerna, Tbk yang Terdaftar di Bursa Efek Indonesia', JURNAL AKUNTANSI STIE SULTAN AGUNG, 5(2), pp. 15-22. 
[28] Tiarasandy, A., Yuliandari, W. S. and Triyanto, D. N. (2018) 'PENGARUH KINERJA LINGKUNGAN DAN PENGUNGKAPAN CORPORATE SOCIAL RESPONSIBILITY TERHADAP KINERJA FINANSIAL ( Studi Empiris pada Perusahaan yang Terdaftar di PROPER Periode 2013-2015 )', e-Proceeding of Management, 5(1), pp. 678-688.

[29] Umiyati, U. and Baiquni, M. D. (2018) 'Ukuran Perusahaan , Profitabilitas , Dan Leverage Terhadap Islamic Social Reporting Pada Bank Umum Syariah Di Indonesia', Jurnal Akuntansi Dan Keuangan Islam, 6(1), pp. 85-104.

[30] Vithessonthi, C. and Tongurai, J. (2015) 'The effect of firm size on the leverageperformance relationship during the financial crisis of 2007-2009', Journal of Multinational Financial Management. Elsevier B.V., 29, pp. 1-29. doi: 10.1016/j.mulfin.2014.11.001.

[31] Warrad, L. H. (2017) 'The Influence of Leverage and Profitability on Earnings Quality: Jordanian Case', International Journal od Academic Research in Business and Social Sciences, 7(10), pp. 62-81. doi: 10.6007/IJARBSS/v7-i10/3359.

[32] Zariyawati, M. A., Annuar, M. N. and Pui-San, N. (2016) 'Working capital management determinants of small and large firms in malaysia', International Journal of Economics and Management, 10(2), pp. 365-377. doi: 10.1016/S00963003(03)00233-9. 